\title{
Budaya Kerja WFH di Masa Pandemi COVID-19 : Dampaknya terhadap Produktivitas Karyawan di Industri Ritel
}

\author{
William Widjaja ${ }^{1}$, Marco Ashadi $^{2}$, Verina Cornellia ${ }^{3}$ \\ ${ }^{1}$ Universitas Pradita, william.widjaja@pradita.ac.id \\ ${ }^{2}$ Universitas Pradita, marco.ashadi@pradita.ac.id \\ ${ }^{3}$ Universitas Pradita, verina.cornellia@ student.pradita.ac.id
}

\begin{abstract}
The COVID-19 pandemic that has occurred since the beginning of 2020 has had a considerable impact on community life in the world, especially in Indonesia. Efforts to prevent the corona virus by implementing rules for work, study, at home. The company's performance will increase if its employees have comparable productivity. During this pandemic,enterpreneur who carry out their activities by asking their employees to remain productive by completing their work from home or what is commonly called work from home (WFH). Employee work productivity is very important in encouraging company performance so that the company can survive and compete in this Covid-19 pandemic, where employee work productivity is very effective by a new work culture called WFH. Based on the results of statistical tests which show the results that partially WFH work culture has a positive and significant effect on employee work productivity at PT. Asiana Anugerah Lestari. Furthermore, the results of the unpaired t-test show that there is no significant difference between the productivity of employees who have or have not had children. This result is in line with the descriptive statistics which show that $40 \%$ of respondents said nothing at all during WFH and 60\% experienced technical problems. This study aims to see the effectiveness of work in the retail industry during a pandemic and the extent to which work from home has an effect on work productivity in the food and beverage retail industry.
\end{abstract}

Keywords : WFH, industry, retail, productivity, employee

\begin{abstract}
ABSTRAK
Pandemi COVID-19 yang telah terjadi semenjak awal tahun 2020 telah memberikan dampak yang cukup besar terhadap kehidupan bermasyarakat di dunia khususnya di Indonesia. Upaya pencegahan virus corona dengan diberlakukannya aturan bekerja, belajar, beribadah di rumah. Kinerja perusahaan akan meningkat jika karyawannya memiliki produktivitas yang sebanding. Di masa pandemi ini, pelaku bisnis melakukan aktivitasnya dengan meminta karyawannya untuk tetap produktif dengan menyelesaikan pekerjaannya dari rumah atau yang biasa disebut work from home (WFH). Produktivitas kerja karyawan amat sangat penting di dalam mendorong kinerja perusahaan agar perusahaan tetap mampu bertahan dan bersaing di masa pandemi Covid-19 ini yang mana, produktivitas kerja karyawan sangat dipengaruhi oleh budaya kerja baru yang disebut dengan WFH. Berdasarkan hasil uji statistik yang dilakukan menunjukkan hasil bahwa budaya kerja WFH secara parsial berpengaruh positif dan signifikan terhadap produktivitas kerja karyawan di PT. Asiana Anugerah Lestari. Selanjutnya, hasil uji t tidak berpasangan menunjukkan bahwa tidak ada perbedaan yang nyata antara produktivitas karyawan yang telah memiliki anak ataupun belum memiliki anak. Hasil ini sejalan dengan statistik deskriptif yang menunjukkan bahwa $40 \%$ responden mengatakan tidak memiliki kendala sama sekali selama WFH dan 60\% mengalami kendala teknis. Penelitian ini bertujuan untuk mengetahui bagaimana produktivitas kerja karyawan di industri ritel di masa pandemi dan sejauh mana pengaruh work from home terhadap produktivitas kerja di industri food and beverage retail.
\end{abstract}

Kata Kunci : WFH, industri, ritel, produktivitas, karyawan

Naskah diterima: 04-05-2021, direvisi: 21-04-2021, diterbitkan: 01-06-2021 


\section{PENDAHULUAN}

Pandemi COVID-19 yang telah terjadi semenjak awal tahun 2020 telah memberikan dampak yang cukup besar terhadap kehidupan bermasyarakat di dunia khususnya di Indonesia. Semenjak pandemi COVID-19 ditetapkan, pemerintah Indonesia melakukan kampanye dengan jargon "bekerja, belajar dan beribadah di rumah" yang artinya meminta masyarakat untuk melakukan segala aktivitasnya dari rumah dengan mengunakan media internet sebagai alat komunikasi. Hal ini dilakukan untuk menekan tingkat penyebaran COVID19 yang semakin meluas di beberapa wilayah di Indonesia. Selain kampanye tersebut, pemerintah juga mengeluarkan berbagai paket kebijakan dan aturan mulai dari tingkat pusat, daerah, hingga kabupaten kota yang salah satunya melarang beberapa sektor untuk menghentikan aktivitasnya dan memberikan pengecualian untuk beberapa sektor lainnya untuk tetap menjalankan aktivitasnya dengan memberlakukan prokotol kesehatan yang ketat. Kebijakannya ini tentunya sangat berpengaruh negatif terhadap pertumbuhan ekonomi negara karena ruang gerak berbagai sektor bisnis yang menjadi sangat sempit sehingga sulit bertumbuh. Berdasarkan data yang dikeluarkan oleh Badan Pusat Statistik (BPS) pertumbuhan ekonomi Indonesia di kuartal ke dua 2020 menunjukkan minus 5,32 persen hal ini disebabkan dari 17 sektor ekonomi yang dimiliki, 10 sektor mengalami penurunan dan 6 sektor lainnya meningkat tipis dan stagnan serta hanya 1 sektor yang mengalami pertumbuhan yang sangat signifikan yaitu di sektor telekomunikasi (Statistik, 2020).

Dengan kondisi seperti ini, berbagai pelaku bisnis mulai memikirkan dan menerapkan berbagai strategi agar mampu bertahan hingga meningkatkan kinerja bisnisnya. Hamid, Maheen, Cheem, \& Yaseen (2017) menyampaikan bahwa kinerja perusahaan dapat ditingkatkan melalui program kegiatan manajemen sumber daya manusia yang mengarah pada peningkatan produktivitas karyawan. Sugiyarto (2016) menjelaskan bahwa naik dan turunnya kinerja suatu organisasi bisnis sangat berhubungan erat dengan produktivitas karyawannya. Irawati (2018) menambahkan bahwa perusahaan mampu bersaing jika memiliki kinerja perusahaan yang baik dengan didukung oleh produktivitas karyawan yang tinggi. Dari beberapa pendapat dapat disimpulkan bahwa kinerja perusahaan akan meningkat jika karyawannya memiliki produktivitas yang sebanding.

Di masa pandemi ini, pelaku bisnis melakukan aktivitasnya dengan meminta karyawannya untuk tetap produktif dengan menyelesaikan pekerjaannya dari rumah atau yang biasa disebut work from home (WFH). WFH identik dengan melakukan pekerjaan kantor, rapat, diskusi, dan koordinasi dengan rekan dan atau mitra kerja dari rumah pegawai masing-masing secara online. Adapun pilihan media yang digunakan bisa berupa voice call, chat atau text messenger, dan confrence call audio/video. Beberapa pilihan aplikasi video conference pun saat ini beragam seperti Google Meet, Microsoft Team, Zoom, Skype dan lain sebagainya. Menurut Mustajab et al., (2020) berpendapat bahwa WFH memberikan dampak positif maupun negatif terhadap produktivitas kerja. Selain itu, penelitiannya juga menemukan bahwa secara menyeluruh produktivitas karyawan cenderung menurun pada masa WFH disebabkan karena kurangnya fasilitas penunjang pekerjaan seperti komputer, jaringan internet dan beberapa gangguan lainnya seperti perasaan jenuh karena berada di lingkungan yang sama dalam waktu yang relative cukup lama dengan keterbatasan kehidupan sosial. Purwanto (2020) juga menjelaskan bahwa WFH memberikan keuntungan dan kerugian bagi kinerja karyawan seperti lebih fleksibel dalam menyelesaikan pekerjaan, tidak mengikuti jam masuk kantor, tidak perlu mengeluarkan uang untuk membayar ongkos transportasi atau biaya bensin, bisa meminimalisir tingkat stres yang dialami akibat kemacetan lalu lintas dari rumah menuju kantor sedangkan kerugian dari WFH adalah potensi kehilangan motivasi kerja, kenaikan biaya listrik dan internet karena tidak dapat menggunakan fasilitas 
kantor hingga dapat menimbulkan masalah keamanan data.

Berdasarkan urian tersebut maka dapat disimpulkan bahwa produktivitas kerja karyawan amat sangat penting di dalam mendorong kinerja perusahaan agar perusahaan tetap mampu bertahan dan bersaing di masa pandemi Covid-19 ini yang mana, produktivitas kerja karyawan sangat

\section{KAJIAN LITERATUR Industri Ritel}

Ritel menurut Berman B \& Evans J (2018) menjelaskan bahwa ritel merupakan suatu usaha bisnis di dalam memasarkan barang atau jasa terhadap konsumen akhir yang digunakan untuk keperluan pribadi maupun rumah tangga. Dari berbagai pendapat tersebut maka, dapat disimpulkan bahwa industri ritel merupakan industri bisnis yang aktivitasnya memberikan upaya maksimal melalui strategi bauran ritel agar barang atau jasa yang ditawarkan ke end user memiliki nilai tambah (added value) sehingga konsumen merasa puas (satisfy) terhadap produk atau jasa yang telah dibeli.

Berbagai penelitian telah dilakukan terkait industri ritel. Berbagai sektor industri terkena dampak pandemi Covid-19 sehingga perekonomian menurun. Kartikaningsih \& Nugraha (2020) menjelaskan bahwa dampak pada industri ritel dinilai medium. Artinya, industri ritel masih bisa bertahan di tengah pandemi, meskipun mengalami penurunan. Penelitian yang dilakukan di PT Lottemart Wholesale07 oleh Darono (2019) menjelaskan bahwa perusahaan ritel yang ada saat ini terus mengembangkan strategi usahanya dengan cara melakukan penembusan pasar dan strategi penetapan harga, jadi baik dari sistem informasi maupun dari sisi manajemen terus diperbaiki agar mampu bersaing di tengah kondisi penjualan yang menurun cukup signifikan.

\section{Produktivitas}

Produktivitas kerja karyawan merupakan faktor penting di dalam mendorong kinerja organisasi sehingga organisasi mampu terus bersaing dan mampu bertahan dari waktu ke waktu di segala kondisi yang dihadapi khususnya di dipengaruhi oleh budaya kerja baru yang disebut dengan WFH. Penelitian ini bertujuan untuk mengetahui bagaimana produktivitas kerja karyawan di industri ritel di masa pandemi, dan sejauh mana pengaruh WFH terhadap produktivitas kerja di industri food and beverage retail.

masa pandemi Covid-19. Mathis \& Jackson (2012) mengartikan produktivitas sebagai ukuran dari kuantitas dan kualitas dari pekerja yang telah dikerjakan dengan memertimbangkan biaya sumber daya yang digunakan untuk mengerjakan pekerjaan tersebut guna melihat rasio antara input dan output. Sinungan (2014) menjelaskan bahwa produktivitas merupakan sebuah konsep dimana menciptakan lebih banyak barang dan jasa (output) bagi kehidupan manusia, dengan menggunakan sumber daya yang serba terbatas. Dari beberapa pendapat tersebut maka dapat disimpulkan bahwa produktivitas kerja merupakan kemampuan di dalam memperoleh manfaat sebesarbesarnya dari sumber daya yang tersedia dengan menghasilkan output semaksimal mungkin.

Berbagai penelitian telah dilakukan terkait produktivitas kerja. Sumarni (2020) menunjukkan bahwa adanya pembatasan aktivitas untuk mencegah Covid-19 menyebabkan terganggunya rantai pasokan dan juga perubahan ketenagakerjaan akibat work from home. Hal ini menurunkan produktivitas dari industri ritel. Asbari, Novitasari \& Sestri (2020) menyebutkan untuk menciptakan kesiapan berubah pada diri karyawan dilakukan dengan menumbuhkan nilai-nilai positif dari karyawan sehingga perubahan yang dilakukan untuk bisa terus berproduktif dapat mencapai kesuksesan yang diharapkan. Dampak wabah Covid-19 kepada perekonomian dialami oleh seluruh negara, termasuk industri ritel. Penelitian Nalini (2021) menyebutkan dengan adanya Covid-19 transformasi digital perlu dilakukan demi mendukung usaha pengusaha. Berjalannya usaha harus diimbangi dengam produktivitas dari 
industri tersebut, walaupun terkendala oleh keadaan seperti pembatasan tenaga kerja.

Nasution, Mahargiono \& Soesatyo (2016) melakukan penelitian dengan tujuan menganalisis pengaruh antara gaya kepemimpinan, suasana organisasi dan etos kerja terhadap produktivitas di PT HP Metals Indonesia. Dimana pada penelitian tersebut produktivitas diukur melalui tiga aspek yakni; kuantitas kerja, kualitas kerja dan ketepatan waktu penyelesaian. Sejalan dengan Hanaysha (2016) bahwa produktivitas dapat diukur melalui jumlah output pekerjaan, kecepatan dan efesiensi kerja, kualitas pekerjaan dan ketercapaian target. Dari beberapa pendapat tersebut maka, penelitian ini akan mengukur produktivitas berdasarkan: kuantitas dan kualitas kerja yang dihasilkan serta ketepatan waktu dalam penyelesaian tugas atau pekerjaan.

\section{Working From Home (WFH)}

Di masa pandemi COVID-19 banyak perusahaan yang menerapkan WFH agar perusahaan tetap bisa produktif. WFH merupakan sebuah cara bekerja yang dilakukan dari rumah dengan menggunakan media internet sebagai alat komunikasi. Bloom (2015) menjelaskan bahwa WFH juga biasa disebut sebagai telecommuting atau telework sebenarnya bukanlah hal yang baru dalam dunia kerja. Begitupun Mungkasa (2020) menyampaikan bahwa WFH adalah pengaturan bekerja leluasa yang memungkinkan bekerja jauh dari kantor sepanjang atau sebagian waktu. Penelitian Ilham (2020) menunjukkan bahwa Work From Home menjadi kendala dalam menjalankan suatu usaha, namun dengan era digital saat ini strategi dalam pemanfaatan teknologi menjadi solusi untuk tetap menjaga kualitas maupun pelayanan suatu usaha. Dalam hal penjualan industri ritel masih bisa dilakukan dengan platform online. Strategi dalam produksi industri ritel perlu dikaji ulang.

Berbagai literatur menjelaskan bahwa WFH atau telework identik dengan skema praktek kerja leluasa atau flexible work atau waktu leluasa (flexi time). Menurut Mungkasa (2020) flexi time dibagi menjadi beberapa jenis yaitu: Fixed Working Hours yaitu sistem kerja yang memungkinkan karyawan dapat dengan bebas memilih sesi kerjanya setiap hari sesuai ketetapan perusahaan sepanjang memenuhi jumlah minimal 40 jam seminggu, Flexible Working Hours yaitu sistem kerja yang memungkinkan pegawai bekerja leluasa sepanjang memenuhi jumlah waktu minimal adalah 40 jam per minggu, dan Variable Working Hours yaitu sistem kerja yang mengharuskan pegawai hadir pada jam tertentu di kantor dan pegawai dapat menetapkan sendiri waktu selebihnya. Penelitian yang dilakukan Vries, Tummers \& Bekkers (2019) membagi WFH menjadi dua jenis yaitu bekerja penuh waktu dari rumah (working fully form home) dan bekerja sebagian waktu dari rumah (working partly from home). Berdasarkan uraian tersebut maka, penelitian ini memiliki hipotesis sebagai berikut:

Ho1: Tidak ada pengaruh signifikan antara budaya kerja WFH terhadap produktivitas kerja.

Ha1: Terdapat pengaruh signifikan antara budaya kerja WFH terhadap produktivitas kerja.

Ho2: Tidak ada perbedaan produktivitas secara nyata antara karyawan yang memiliki anak dengan yang tidak memiliki anak.

Ha2: Terdapat perbedaan produktivitas secara nyata antara karyawan yang memiliki anak dengan yang tidak memiliki anak.

Ho3: Tidak ada perbedaan produktivitas secara nyata antara karyawan yang memiliki gangguan dengan yang tidak.

Ha3: Terdapat perbedaan produktivitas secara nyata antara karyawan yang memiliki gangguan dengan yang tidak.

\section{METODE PENELITIAN}

Objek dalam penelitian ini adalah karyawan PT. Asiana Anugerah Lestari yang berjumlah \pm 50 orang. Teknik pengumpulan data menggunakan kuesioner dengan teknik sampel yang digunakan adalah nonprobability sampling 
dengan metode purposive sampling yaitu mengambil sampel dari populasi yang ada dengan ciri-ciri tertentu yang sesuai dengan tujuan penelitian sehingga diharapkan mampu menjawab pertanyaan atau rumusan penelitian. Adapun ciri-ciri responden yang akan dijadikan sampel, antara lain: karyawan bekerja secara WFH, karyawan memiliki tugas atau pekerjaan yang masih memungkinkan untuk dilakukan secara WFH, dan karyawan yang anggota keluarganya juga harus melakukan kegiatan (bekerja, sekolah atau kuliah) di rumah.

Teknik analisis data yang digunakan adalah statistik deskriptif dan inferensial dengan menggunakan analisis regresi sederhana untuk mencari tahu hubungan kausalitas antar variabel. Skala likert adalah skala psikometrik yang biasa digunakan pada data kuesioner, biasanya pada penelitian berupa survei (Sugiyono, 2012). Dengan menggunakan skala likert, maka variabel yang akan diukur dijabarkan menjadi indikator variabel.

Tabel 1. Bobot Penilaian Skala Likert

\begin{tabular}{ll}
\hline Jawaban & Bobot Penilaian \\
\hline Sangat Setuju & 5 \\
\hline Setuju & 4 \\
\hline Netral & 3 \\
\hline Tidak Setuju & 2 \\
\hline Sangat Tidak Setuju & 1 \\
\hline Sumber: (SugiyOn
\end{tabular}

Sumber: (Sugiyono, 2012)

\section{PEMBAHASAN}

\section{Uji Validitas}

Uji validitas digunakan untuk mengukur keabsahaan dari suatu pernyataan pada kuesioner di dalam mengukur suatu variabel. Melihat validitas sebuah instrumen adalah dengan membandingkan nilai dari corrected item-total correlation dengan nilai $\mathrm{r}$ tabel. Jika nilai corrected item-total correlation lebih besar dari $\mathrm{r}$ tabel maka dikatakan valid dan sebaliknya jika lebih kecil maka tidak valid. Syarat validitas pada penelitian ini adalah jika $r$ hitung $\geq 0,361$ dengan level signifikansi 5\%. Hasil uji validitas instrumen pada penelitian ini adalah sebagai berikut:
Metode penelitian ini digunakan untuk memperoleh angka penafsiran pada kuesioner. Pada umumnya, untuk menentukan besarnya kelas (panjang interval) digunakan rumus:

$C=\frac{X n-X 1}{k}$

Dimana:

$\mathrm{C}=$ perkiraan besarnya (class width, class size, class length)

$\mathrm{K} \quad$ = banyaknya kelas

$\mathrm{Xn} \quad=$ nilai observasi terbesar

$\mathrm{X} 1=$ nilai observasi terkecil

Adapun rumus penafsiran yang digunakan adalah:

$M=\frac{\Sigma f(x)}{n}$

Keterangan:

$\mathrm{M}=$ Angka penafsiran

$\mathrm{f} \quad=$ Frekuensi jawaban

$\mathrm{x}=$ Skala nilai

$\mathrm{n} \quad=$ Jumlah seluruh jawaban

Hipotesis untuk menentukan pengaruh antar variabel pada penelitian ini adalah sebagai berikut:

Indikator variabel dalam penelitian, meliputi kuantitas, kualitas, dan ketepatan waktu penyelesaian. Indikator kuantitas diukur dari target perusahaan, produktivitas, dan beban kerja. Indikator kualitas, meliputi kesalahan kerja, standar kualitas perusahaan, dan komplain. Ketepatan waktu penyelesaian, meliputi on time dan in time.

Tabel 2. Uji Validitas Tahap 2

\begin{tabular}{llll}
\hline Indikator & rhit & rtab & Kesimpulan \\
\hline $\begin{array}{l}\text { Kuantitas } \\
\text { kerja }\end{array}$ & 0,582 & 0,361 & Valid \\
\hline & 0,492 & 0,361 & Valid \\
\hline Kualitas Kerja & 0,444 & 0,361 & Valid \\
\cline { 2 - 4 } & 0,367 & 0,361 & Valid \\
\hline $\begin{array}{l}\text { Ketepatan } \\
\text { waktu } \\
\text { penyelesaian }\end{array}$ & 0,393 & 0,361 & Valid \\
\cline { 2 - 4 } & 0,463 & 0,361 & Valid \\
\hline Sumber & 0,444 & 0,361 & Valid \\
\hline
\end{tabular}

Sumber: Pengolahan Data (2020)

Tabel 2 menujukkan bahwa setelah dilakukan pengujian ulang menghasilkan seluruh pernyataan memiliki nilai rhit yang lebih besar dari nilai rtab yang artinya 
seluruh pernyataan dinyatakan valid sehingga dapat dilakukan uji statistik lebih lanjut.

\section{Uji Reliabilitas}

Uji Reliabilitas digunakan untuk mengukur suatu kuesioner yang merupakan indikator dari variabel atau konstruk. Butir pernyataan dikatakan reliabel atau handal apabila jawaban seseorang terhadap pertanyaan adalah konsisten. Salah satu metode pengujian realibilitas adalah dengan menggunakan metode alpha cronbach $(\alpha)$. Tingkat realibilitas dengan metode alpha conbrach diukur berdasarkan skala 0 sampai 100. Jika nilai alpha conbrach di atas $70 \%$ $(0,7)$ maka dapat dikatakan reliabel. Berikut adalah hasil uji reliabilitas pada penelitian ini dengan menggunakan alat bantu perangkat lunak IBM SPSS versi 22:

Tabel 3. Hasil Uji Reliabilitas

\begin{tabular}{llll}
\hline Variabel & $\begin{array}{l}\text { Nilai } \\
(\boldsymbol{\alpha})\end{array}$ & $\begin{array}{l}\text { Syarat } \\
(\boldsymbol{\alpha})\end{array}$ & Kesimpulan \\
\hline $\begin{array}{l}\text { Produktivitas } \\
\text { kerja }\end{array}$ & 0,722 & 0,70 & Reliabel \\
\hline Sumber: Pengolahan Data $(2020)$ &
\end{tabular}

Sumber: Pengolahan Data (2020)

Berdasarkan tabel 3 dapat dilihat bahwa instrumen yang digunakan pada penelitian ini reliabel atau secara konsisten dapat mengukur variabel produktivitas kerja sehingga dapat dilakukan pengujian statistik lebih lanjut.

\section{Uji Normalitas}

Uji normalitas merupakan salah satu uji asumsi sebagau salah satu syarat yang harus dipenuhi untuk membangun suatu persamaan regresi sederhana. Persamaan regresi dikatakan baik jika mempunyai data variabel bebas dan data variabel terikat berdistribusi mendekati. Penelitian ini menggunakan uji kolmogorov smirnov untuk mengetahui apakah data berdistribusi normal atau tidak. Syarat data dapat dikatakan berdistribusi normal jika nilai signifikansi lebih besar dari 0,05. Berikut adalah hasil uji kolmogorov smirnov:
Tabel 4. Hasil Uji Normalitas

\begin{tabular}{lll}
\hline Nilai & Syarat & Kesimpulan \\
\hline 0,219 & 0,05 & Berdistribusi normal \\
\hline \multicolumn{2}{l}{ Sumber: Pengolahan Data $(2020)$}
\end{tabular}

Tabel 4 menunjukkan bahwa nilai signifikansi sebesar 0,219>0,05 yang dapat diartikan bahwa data berdistribusi normal dan dapat dilakukan pengujian regresi sederhana.

\section{Regresi Linear Sederhana}

Regresi linear sederhana adalah suatu metode statistik yang berfungsi untuk menguji sejauh mana hubungan sebab akibat antara variabel bebas dengan variabel terikat. Hasil uji regresi linear sederhana dengan IBM SPSS 22 adalah sebagai berikut:

Tabel 5. Signifikansi budaya kerja WFH

\begin{tabular}{lllll}
\hline Model & \multicolumn{2}{l}{$\begin{array}{l}\text { Unstandardized } \\
\text { Coefficients }\end{array}$} & $\begin{array}{l}\text { Standardized } \\
\text { Coefficients }\end{array}$ & Sig. \\
\cline { 2 - 5 } & B & $\begin{array}{l}\text { Std. } \\
\text { error }\end{array}$ & & \\
\hline (Constant) & 34.828 & .544 & & .000 \\
\hline WFH & 10.172 & 2.979 & .542 & .002 \\
\hline
\end{tabular}

Sumber: Pengolahan Data (2020)

Berdasarkan tabel 5 maka persamaan regresi linear sederhana yang dihasilkan pada penelitian ini adalah

$Y=34,828+10,172$

Dari persamaan tersebut dapat disimpulkan bahwa secara statistik nilai dari produktivitas karyawan di PT Asiana Anugerah Lestari adalah sebesar 45 yang berasal dari nilai konstanta sebesar 34,828 di tambah koefisien dari budaya kerja WFH yaitu 10,172 . Secara statistik artinya adalah setiap budaya kerja WFH ditingkatkan satu satuan unit maka nilai produktivitas akan meningkat sebesar 10,172 dengan standar error untuk persamaan ini adalah sebesar 2,979 .

\section{Uji t (uji parsial)}

Uji t atau dikenal dengan uji parsial merupakan pengujian yang dilakukan untuk mencari tahu pengaruh variabel bebas secara sendiri-sendiri terhadap variabel terikatnya. Uji ini dapat dilakukan dengan 
membandingkan nilai $\mathrm{t}$ hitung dengan nilai $\mathrm{t}$ tabel. Pada taraf signifikansi 5\% maka, budaya WFH dapat dikatakan berpengaruh terhadap produktivitas kerja apabila nilai $\mathrm{t}$ hitung lebih besar dari 2,048. Pada tabel 5.7 terlihat bahwa nilai t hitung adalah sebesar $3,415>2,048$ yang artinya bahwa hipotesis alternatif dapat diterima sehingga dapat disimpulkan bahwa terdapat pengaruh positif dan signifikan antara budaya kerja WFH terhadap produktivitas karyawan di PT Asiana Anugerah Lestari.

\section{Uji t Tidak Berpasangan}

Uji t tidak berpasangan yaitu sebuah uji statistik untuk mengetahui apakah terdapat perbedaan nyata atau tidak antara satu sampel dengan sampel lainnya yang tidak berpasangan. Teknik pengambilan keputusan pada uji adalah jika nilai signifikansi two tailed $\leq 0,05$ maka, hipotesis nol ditolak dan menerima hipotesis alternatif. Terdapat dua hipotesis yang perlu diuji yaitu:

Ho1: Tidak ada perbedaan produktivitas secara nyata antara karyawan yang memiliki anak dengan yang tidak memiliki anak

Ha1: Terdapat perbedaan produktivitas secara nyata antara karyawan yang memiliki anak dengan yang tidak memiliki anak

Ho2: Tidak ada perbedaan produktivitas secara nyata antara karyawan yang memiliki gangguan dengan yang tidak

$\mathrm{Ha} 2$ : Terdapat perbedaan produktivitas secara nyata antara karyawan yang memiliki gangguan dengan yang tidak.

Hasil uji t tidak berpasangan terhadap dua hipotesis tersebut adalah sebagai berikut:

Tabel 6. Uji t tidak berpasangan berdasarkan kepemilikan anak

\begin{tabular}{lcccc}
\hline & $\begin{array}{c}\text { Levene's Test } \\
\text { for Equality of } \\
\text { Variances }\end{array}$ & $\begin{array}{c}\text { t-test for Equality } \\
\text { of Means }\end{array}$ \\
\cline { 2 - 5 } & $\mathrm{F}$ & Sig. & $\mathrm{t}$ & $\begin{array}{c}\text { Sig. } \\
(2- \\
\text { tailed })\end{array}$ \\
\hline $\begin{array}{l}\text { Equal } \\
\text { variances } \\
\text { assumed }\end{array}$ & 10.691 & .003 & - & .014 \\
\hline Equal & & & 2.613 & \\
\hline
\end{tabular}

\begin{tabular}{|c|c|}
\hline $\begin{array}{l}\text { variances } \\
\text { not } \\
\text { assumed }\end{array}$ & 1.900 \\
\hline
\end{tabular}

Sumber: Pengolahan Data (2020)

Hasil uji signifikansi pada Levene's test menunjukkan nilai signfikansi sebesar 0,03 $<0,05$ yang artinya tidak ada kesamaan varians data antara dua kelompok sehingga nilai signifkansi yang digunakan untuk pengambilan keputusan adalah nilai signifikansi pada baris equal variances not assumed yaitu sebesar 0,090 > 0,05 yang artinya adalah menerima hipotesis nol yaitu tidak adanya perbedaan nyata antara produktivitas karyawan yang memiliki anak dengan yang tidak memiliki anak.

Tabel 7. Uji t tidak berpasangan berdasarkan kendala WFH

\begin{tabular}{|c|c|c|c|c|}
\hline & \multicolumn{2}{|c|}{$\begin{array}{l}\text { Levene's Test } \\
\text { for Equality } \\
\text { of Variances }\end{array}$} & $\begin{array}{l}\mathrm{t} \text {-test for } \\
\text { of Means }\end{array}$ & \multirow{2}{*}{$\begin{array}{c}\text { Equality } \\
\text { Sig. } \\
\text { (2- } \\
\text { tailed) }\end{array}$} \\
\hline & $\mathrm{F}$ & Sig. & $\mathrm{t}$ & \\
\hline $\begin{array}{l}\text { Equal } \\
\text { variances } \\
\text { assumed } \\
\end{array}$ & .896 & .352 & 1.764 & .089 \\
\hline $\begin{array}{l}\text { Equal } \\
\text { variances } \\
\text { not } \\
\text { assumed }\end{array}$ & & & 1.819 & .080 \\
\hline
\end{tabular}

Sumber: Pengolahan Data (2020)

Hasil uji signifikansi pada Levene's test menunjukkan nilai signfikansi sebesar 0,352 $>0,05$ yang artinya terdapat kesamaan varians data antara dua kelompok sehingga nilai signifkansi yang digunakan untuk pengambilan keputusan adalah nilai signifikansi pada baris equal variances assumed yaitu sebesar 0,089>0,05 yang artinya adalah menerima hipotesis nol yaitu tidak adanya perbedaan nyata antara produktivitas karyawan yang menghadapi kendala saat WFH dengan yang tidak menghadapi kendala saat WFH.

\section{Pengaruh Budaya WFH terhadap Produktivitas Kerja}

Berdasarkan hasil uji statistik yang dilakukan menunjukkan hasil bahwa budaya kerja WFH secara parsial berpengaruh positif dan signifikan terhadap produktivitas 
kerja karyawan di PT. Asiana Anugerah Lestari. Hasil penelitian ini juga sejalan dengan penelitian sebelumnya yang menunjukkan hasil bahwa bekerja dari rumah (WFH) dapat meningkatkan produktivitas kerja (Noonan, \& Glass, 2012; Amador, 2016; Simarmata, 2020).

Selanjutnya, hasil uji t tidak berpasangan menunjukkan bahwa tidak ada perbedaan yang nyata antara produktivitas karyawan yang telah memiliki anak ataupun belum memiliki anak. Dilihat dari hasil statistik deskriptif hal tersebut dapat dijelakan karena hanya sebesar $30 \%$ responden saja yang telah memiliki anak sedangkan $70 \%$ belum memiliki anak. Statistik deskriptif juga menunjukkan hanya $10 \%$ dari $30 \%$ responden yang merasa bahwa mengawasi anak menjadi kendala di dalam melakukan WFH. Dugaan lain yang memungkinkan hal tersebut terjadi adalah adanya anggota keluarga lain yang membantu mengawasi anak mereka saat mereka harus bekerja dari rumah dan justru dengan WFH motivasi kerja lebih meningkatkan dikarenakan mereka merasa lebih dekat dengan keluarga, stress kerja dapat berkurang karena tidak harus melewati lalu lintas yang relatif padat setiap harinya (Simarmata, 2020).

Selain itu, hasil uji t tidak berpasangan juga menunjukkan bahwa tidak ada perbedaan nyata antara produktivitas karyawan yang memiliki kendala teknis selama WFH dengan yang tidak memiliki kendala teknis. Hasil ini sejalan dengan statistik deskriptif yang menunjukkan bahwa $40 \%$ responden mengatakan tidak memiliki kendala sama sekali selama WFH dan 60\% mengalami kendala teknis seperti jaringan internet yang lemot, komunikasi dengan klien, mengawasi anak sekolah online, koordinasi dengan tim, rekan maupun pimpinan. Namun, kendalakendala teknis tersebut dapat ditangani oleh karyawan seperti; internet yang lemot, mereka dapat mencari tempat atau lokasi diluar rumah yang memiliki sarana internet dengan koneksi yang cepat terbukti terdapat $40 \%$ responden yang tidak selalu bekerja di rumah, dan 23\% responden yang justru tidak bekerja di rumah. Komunikasi dengan klien dan koordinasi dengan tim, rekan maupun pimpinan juga tetap dapat ditangani dengan menggunakan teknologi seperti platform zoom, gmeet, skype, dll. Apalagi karyawankaryawan di PT Asiana Anugerah Lestari berada dijarak usia 22-35 tahun yang artinya diisi oleh karyawan-karyawan dari generasi millennial maupun generasi $\mathrm{Z}$ yang secara karakteristik sangat fasih di dalam mengadopsi teknologi sehingga kendalakendala teknis terkait penggunaan teknologi dapat tertangani dengan baik. Disamping itu, budaya WFH yang sudah terbentuk hampir satu tahun semenjak penelitian ini dilakukan memberikan implikasi baik secara individu maupun kolektif atau organisasi. Secara individu selama WFH karyawan merasakan kualitas kerja yang lebih baik maupun lebih produktif dikarenakan minimnya waktu yang dihabiskan untuk mengobrol serta kegiatan lain yang dianggap kurang penting antar kolega sehingga karyawan dapat lebih fokus dan menjadi lebih produktif. Selain itu, keseimbangan antara kehidupan kerja dan pribadi dirasakan lebih baik serta stress kerja menurun dikarenakan karyawan dapat mengatur waktu kerja mereka lebih fleksibel dan tidak perlu ke tempat kerja setiap hari yang dapat menguras energi fisik ketika menempuh jarak dari tempat tinggal ke tempat dimana mereka bekerja. Dari sisi organisasi, budaya WFH meningkatkan efisiensi dari sisi biaya transportasi, insentif lembur dan operasional kantor dikarenakan karyawan menggunakan sumber daya yang dimiliki secara individu.

\section{SIMPULAN}

Berdasarkan hasil uji statistik yang telah dilakukan maka, kesimpulan dari hasil penelitian ini adalah terdapat pengaruh positif dan signifikan antara budaya kerja WFH dengan produktivitas karyawan di PT Asiana Anugerah Lestari. tidak ada perbedaan nyata antara produktivitas karyawan yang telah memiliki anak maupun belum. Tidak ada perbedaan nyata antara produktivitas karyawan yang memiliki kendala teknis selama WFH maupun yang tidak memiliki kendala.

Saran yang bisa diberikan yaitu pada penelitian ini terbatas pada sistem kerja WFH di dalam mengukur produktivitas kerja. Bagi peneliti yang tertarik untuk 
melakukan riset lebih jauh terkait ini dapat menambahkan variabel-variabel lainnya seperti motivasi kerja, stress kerja, lingkungan kerja. Selain itu, untuk melakukan generalisasi pada penelitian ini, peneliti selanjutnya dapat melakukan kepada beberapa industri food and beverage lainnya dengan jumlah responden yang lebih besar.

\section{REFERENSI}

Amador, J. M. (2016). Remote and OnSite Knowledge Worker Productivity and Engagement: A Comparative Study of The Effect of Virtual Intensity and Work Location Preference. Ohio: Case Western Reverse University.

Asbari, M., Novitasari, D., \& Sestri, F. (2020). JMK (Jurnal Manajemen dan Kewirausahaan) Mempertahankan Kinerja Karyawan di Masa Pandemi Covid19: Studi Kasus pada Industri Ritel. Jurnal Manajemen Dan Kewirausahaan, 5(3), 183-203.

Berman B, Evans J, \& C. P. (2018). Retail Management: A Strategic Approach, Global Edition. New Jersey: Pearson Education Limited.

Bloom. (2015). Does Working From Home Work? Evidence from A Chinese Experiment. The Quarterly Journal of Economics, 165-218. https://doi.org/10.1093/qje/qju032. Advance

Darono. (2019). Inti nusa mandiri. 13(2), 1-8.

Hamid, M., Maheen, S., Cheem, A., \& Yaseen, R. (2017). Impact of Human Resource Management on Organizational Performance.

Journal of Accounting \& Marketing, $\quad$ 06(01), 1-7. https://doi.org/10.4172/21689601.1000213

Hanaysha, J. (2016). Improving employee productivity through work engagement: Empirical evidence from higher education secto. Management Science Letter, 61-70.

Ilham. (2020). Kondisi Pengusaha Muda Indonesia Di Tengah Pandemi Covid-19 ( Work From Home Dan Strategi Survive ). 4(1), 59-69.

Irawati, R. (2018). Pengaruh Produktivitas Karyawan, Kepuasan Karyawan Dan Turn Over Terhadap Keunggulan Bersaing Perusahaan Melalui Kinerja Karyawan. Jurnal Administrasi Dan Bisnis, 1-15. https://doi.org/http://dx.doi.org/10.3 3795/j-adbis.v12i1.35

Kartikaningsih, D., \& Nugraha. (2020). Pengaruh Nilai Tukar Terhadap Harga Saham Perusahaan Sektor Food and Beverage Di Masa Pandemi Covid-19. BISMA: Jurnal Bisnis Dan Manajemen, 14(2), 133. https://doi.org/10.19184/bisma.v14i 2.17862

Mathis, R. L., \& Jackson, J. H. (2012). Manajemen Sumber Daya Manusia Buku 1 Alih Bahasa: Jimmy Sadeli dan Bayu Prawira Hie. Jakarta: Salemba Empat.

Mungkasa, O. (2020). Bekerja dari Rumah ( Working From Home / WFH ): Menuju Tatanan Baru Era Pandemi COVID 19. The Indonesian Journal of Development Planning, 4(2), 126-150.

Mustajab, D., Bauw, A., Rasyid, A., Irawan, A., Akbar, M. A., \& Hamid, M. A. (2020). Fenomena Bekerja dari Rumah sebagai Upaya Mencegah Serangan COVID-19 dan Dampaknya terhadap Produktifitas Kerja. The International Journal of Applied Business, 4(9), 1689-1699. https://doi.org/10.20473/tijab.V4.I1. 2020.13-21

Nalini, S. N. L. (2021). Dampak covid19 terhadap Usaha Mikro, Kecil 
dan Menengah. Jurnal Ekonomi \& Ekonomi Syariah, 4(1), 662-669. https://doi.org/https://doi.org/10.36 778/jesya.v4i1.278

Nasution, A. P., Mahargiono, P. B., \& Soesatyo, Y. (2016). Effect of Leadership Styles, Organizational Climates and Ethos of Work on Employee Productivity (PT. HP Metals Indonesia The Powder Coating). Dimensi, 1-15.

Noonan, M. C., \& Glass, J. L. (2012).

The Hard Truth about Telecommuting. Washington: Montly Labor Review.

Purwanto, A. (2020). Stude Eksplorasi Dampak Work From Home (WFH) terhadap Kinerja Guru selama Pandemi Covid-19. Journal of Education, Psychology and Counsleing, 2(1), 92-100.

Simarmata, R. M. (2020). Pengaruh Work From Home terhadap Produktivitas Dosen Politeknik Negeri Ambon. Jurnal Ekonomi, Sosial Dan Humaniora, 2(1), 7382.

Sinungan, M. (2014). Produktivitas: Apa dan Bagaimana. Jakarta: Bumi Aksara.

Statistik, B. P. (2020). Ekonomi Indonesia Triwulan II 2020 Turun 5,32 Persen. Retrieved from Badan Pusat Statistik website: https://www.bps.go.id/pressrelease/ 2020/08/05/1737/-ekonomiindonesia-triwulan-ii-2020-turun-532-persen.html

Sugiyarto. (2016). Jurnal Sekretari Vol. 3 No. 2 - Juni 2016 1. 3(2), 1-16.

Sugiyono. (2012). Metode Penelitian Kuantitatif Kualitatif dan $R \& D$. Bandung: Alfabeta.

Sumarni, Y. (2020). Pandemi Covid-19: Tantangan Ekonomi Dan Bisnis. Jurnal Ekonomi Dan Perbankan Syariah, 6(2), 46-58. https://doi.org/http://dx.doi.org/10.2 9300/aij.v6i2.3358

Vries, H. De, Tummers, L., \& Bekkers, V. (2019). The Benefits of

Teleworking in the Public Sector: Reality or Rhetoric? Review of Public Personnel Administration, 39(4), 570-593. https://doi.org/10.1177/0734371X1 8760124 